\title{
Finding Science in Surprising Places: Gender and the Geography of Scientific Knowledge Introduction to 'Beyond the Academy: Histories of Gender and Knowledge'
}

\author{
Christine von Oertzen*, Maria Rentetzi ${ }^{\dagger}$ and Elizabeth S. Watkins ${ }^{\dagger}$
}

\begin{abstract}
The essays in this special issue of Centaurus examine overlooked agents and sites of knowledge production beyond the academy and venues of industry- and government-sponsored research. By using gender as a category of analysis, they uncover scientific practices taking place in locations such as the kitchen, the nursery, and the storefront. Because of historical gendered patterns of exclusion and culturally derived sensibilities, the authors in this volume find that significant contributions to science were made in unexpected places and that these were often made by women. The shift in focus to these different sites and different actors broadens the spectrum of what counts as science and where science happens. That is, in moving beyond the parameters of formal academic structures, this special issue seeks to recast the ways in which the production of science itself is defined and to engage readers in the redesign of the boundaries of our discipline.
\end{abstract}

Keywords. Gender and history of science, scientific practices, sites of knowledge production

A central question for historians of science is: How, where, and by whom has knowledge been produced? With great attention paid to the actors engaged in research within the laboratories and offices of academia, industry, and government agencies, historians have painted a rich portrait of the creation and dissemination of modern scientific knowledge. ${ }^{1}$ But is scientific knowledge production defined only by work conducted within these formalized institutions? The essays in this special issue of Centaurus examine overlooked agents and sites of knowledge production beyond the academy and venues of industryand government-sponsored research. By using gender as a category of analysis, they uncover scientific practices taking place in locations such as the kitchen, the nursery, and the storefront. Because of historical gendered patterns of exclusion and culturally

\footnotetext{
* Max Planck Institute for the History of Science, Dept. II, Boltzmannstraße 22, 14195 Berlin, Germany. Email: coertzen@mpiwg-berlin.mpg.de

${ }^{\dagger}$ National Technical University of Athens, Department of Humanities, Social Sciences and Law, Zografou Campus, Zografou 15780, Athens, Greece. Email: mrentetzi@vt.edu

*University of California, Graduate Division, History of Health Sciences, 1675 Owens Street, CC310, San Francisco, CA 94143-0523, USA. Email: Elizabeth.Watkins@ucsf.edu
} 
derived sensibilities, the authors in this volume find that significant contributions to science were made in unexpected places and that these were often made by women. The shift in focus to these different sites and different actors broadens the spectrum of what counts as science and where science happens. That is, in moving beyond the parameters of formal academic structures, this special issue seeks to recast the ways in which the production of science itself is defined and to engage readers in the redesign of the boundaries of our discipline.

This special issue grew out of a Working Group hosted by the Max Planck Institute for the History of Science in Berlin in June 2010 and July 2011. The group came together with three goals in mind. First, by making the category of gender explicit, they sought to shed light on actors engaged in knowledge production regardless of institutional affiliation or educational background. Drawing on the new 'spatial turn' in the history of science, the second objective was to explore multiple sites of knowledge production and use beyond the academy. ${ }^{2}$ Finally, the participants shared a conviction that divisions between so-called authorized science and popularized science are statusladen and confining constructions that need to be broken down. ${ }^{3}$ In addition, they subscribed to a conception of knowledge flows in scientific work that incorporates dissemination, consumption, and appropriation. When attention is paid to gender and geographies, and when hierarchies of knowledge production are rejected, what emerges is a thriving landscape of communities and individuals producing science and pursuing scholarship, evoking a knowledge society avant la lettre that inspires new, broader definitions of science and the production of knowledge.

For centuries, knowledge production took place in multifunctional spaces such as households and guild shops. With the emergence of scientific societies and academies in the early 17th century and the expansion of the European universities to include research in the early 19th century, the practice of science began to assume large-scale contours. Along with its professionalization and its institutionalization toward the end of the 19th century, science came to be defined mainly by endeavors undertaken within academic research entities. ${ }^{4}$

Whereas researchers in academia labeled the knowledge they created as scientific, they often described knowledge produced beyond their own institutions as applied or artisanal. By the turn of the 20th century, this dichotomy had become hegemonic in many western societies in spatial, material, methodological, and epistemological ways. The work of independent scholars and household-based knowledge practices became categorized as inferior to what was produced within the academy. Boundaries were drawn between professionals and amateurs, academics and popularizers. Historians have shown that struggles involving exclusion from the institutions of science were waged on gendered grounds. ${ }^{5}$ As institutional settings increasingly claimed to represent the very definition of science itself, the performance of science became a predominantly male affair. This volume explores how - despite myriad attempts to establish and maintain scientific knowledge production as a male domain within elite spaces - many women (as well 
as men) continued to practice and to impact science beyond academia. These scholars stretched, challenged, and sometimes modified what was being presented as stable and settled knowledge. Often, they produced notable works that gained recognition from their counterparts within established institutions.

By placing gender at the center of the analyses of sites, practices, and flows of knowledge production beyond academic confines, this volume expands upon recent developments within the history of science that have blurred the boundaries between expert and vernacular knowledge. Emphases on local contexts, material cultures, and specific practices have turned the history of science towards a more comprehensive history of knowledge that takes into account processes of knowledge production and transmission, including their social and cultural conditions and consequences. ${ }^{6}$ By focusing on the gendered dimensions of these processes, this volume offers novel explorations of what has been and should be considered as scientific knowledge.

Each of the following articles examines actors, practices, and flows of knowledge production in sites not tightly connected to learned societies, universities, or research institutes. These sites are understood as both literal and figurative spaces in which women and men engaged in the creation, dissemination, appropriation, and consumption of scientific knowledge. The essays cover the early modern to the modern period with a special emphasis on the late-19th and early-20th centuries, presenting case studies from North America and Western Europe.

Elaine Leong's essay draws attention to the fact that the household occupied the center stage of scientific knowledge production in the early modern period. Focusing on two, 17th-century Fairfax 'family books' and drawing upon a larger survey of over 150, 17th-century British household recipe collections, she demonstrates that the majority of early modern recipe collections were not created by women alone but instead by family collectives working in collaboration across spatial, geographical, and temporal boundaries. Moving to antebellum America, the phrenological cabinet becomes the focal site of Carla Bittel's contribution for exploring the interplay between producing and using scientific knowledge. At a time when science itself had few boundaries, white middle-class men and women became consumers and practitioners of this knowledge system. By encouraging followers to 'know thyself,' phrenology blurred the lines of expertise and the lines of gender, allowing women to venture beyond the bounds of womanhood, without straying too far off the path. Half a century later, in Europe, female sexuality became the subject of widespread scientific, social and political interest as part of the broader 'Woman Question,' inspired in particular by feminists' challenges to the state regulation of prostitution. Kirsten Leng explores the figurative space of public discourse and sexual politics. She examines how and why German feminists employed sexual science to reveal what they believed to be the true nature of female sex drive, thereby establishing as normal a new female sexual subjectivity: that of the sexually autonomous woman who had a biological right to engage in personally enriching (hetero)sexual experiences. As Leng shows, sexual science was not established by male 
physicians alone; instead, she uncovers a broad array of actors including feminists as part of an epistemic community charting new territory deeply enmeshed within turn-of-the century European politics and reform movements.

Educational opportunities in the second half of the 19th century allowed American women to expand their aspirations beyond domestic settings. It was in the interstices between the professions defined as male and occupations defined as female that some enterprising women carved out niches influencing the larger arenas in which they worked. Sally Gregory Kohlstedt explores one such location where a few early 20th-century women found employment, defined activities, and set policies: the museum. Participating in a significant reorientation of public museums, these women transformed education and the dissemination of knowledge both within and beyond the museum walls. When more women gained access to institutions of higher learning toward the end of the 19th century, they sought opportunities to continue their scientific pursuits and intellectual activities after earning their degrees. Christine von Oertzen shows how members of the Association of Collegiate Alumnae - most prominent among them Milicent Shinn, a University of California, Berkeley graduate - established an unprecedented network of at-home research on babies that spanned the North American continent. Von Oertzen's analysis reveals that the caregivers who reported on babies in the home environment understood their observations and experiments to be activities comparable to those of researchers who worked in the academy. Thus, the nursery became a sort of laboratory, blurring distinctions between university and home, expert and amateur.

Turning once again to Europe, where historical scholarship had entertained a strong rapport with scientific practices since the early modern age, Gianna Pomata takes us to the library and the archive, sites that reluctantly offered women limited access. She finds a notable presence of independent scholars among women historians of the first half of the 20th century in Anglophone, French, German, and Italian historiography alike. Pomata contends that independent female scholarship, while often imposed by their exclusion from the academy, could also be a deliberate choice, as the resilience of the older amateur tradition offered a strong counterbalance to women's marginality in academia.

Several themes emerge when these six articles are taken together. The first demonstrates the continuity of extra-academic sites of knowledge production from the early modern period to the 20th century, where women and men worked together in the pursuit of science. In the 17th-century household economies studied by Elaine Leong, wives and husbands, brothers and sisters, uncles and nieces contributed to the compilation of experimentally tested medical recipes. In Carla Bittel's case study of American phrenologists, the household was an extension of the phrenological cabinet and a site where knowledge was consumed and produced. There, married couples utilized theories to read the shape of the skull, thereby practically evaluating themselves and others. For Millicent Shinn and her colleagues, the household became an observatory where babies were the objects of scientific study, as Christine von Oertzen demonstrates in her article. And 
for the independent scholars studied by Gianna Pomata, male family members provided intellectual as well as financial support, and the household functioned as the site of scholarly research. In all of these cases, the household is revealing as an important site where kinship networks played a vital role in the creation and transmission of knowledge.

Kinship was not the only foundation for women's networks of support and exchange. Women also actively sought connections with others working in their field. The importance of these networks for knowledge flows beyond the academy constitutes the second theme that links the essays. The women who studied early childhood development were part of a formally organized national network of home-based scientists. As Christine von Oertzen notes, this network resulted from the connections women made as college students. In similar fashion, Sally Kohlstedt's museum educators sought out one another, often travelling long distances to meet with their peers. The German feminists studied by Kirsten Leng relied on connections within the existing women's and sex reform movements as they circulated their revolutionary appropriation of the science of sexology. These feminists used intimate knowledge of their own bodies to challenge male-generated theories of female sexuality.

That women's gender-based social position facilitated their engagement with scientific pursuits is the third theme that ties these essays together. Men actively recruited women to engage in fields such as phrenology and early childhood development for diverse reasons. In the former, women were presumed to have special qualities that enabled them to pursue phrenology on women and children. In the latter, it was their access to the nursery that gave women entrée into this field.

The fourth and final theme common to the essays in this special issue is the deconstruction of hierarchies of scientific knowledge. While at first glance the museum educators in Kohlstedt's piece seem to be teachers simply engaged in the dissemination of information, their educational programs were innovative and experimental and contributed to new ways of thinking about the scientific study of nature. Similarly, the women who charted their babies' every move may appear as mere lay observers, but in fact they made pioneering contributions to the literature of child development. While the 17th-century recipe books might be dismissed as folk knowledge, they represent clear examples of investigation and compilation consistent with the scientific practices of their time. And, while the historians in Pomata's article seem to be marginal to the practices of scholarship in early-20th century Europe, they produced novel and important studies that influenced their fields for decades.

All of the activities presented in this volume lay at the margins of both contemporary science and historiographical attention. We argue that the margins matter; that is, the margins are not marginal. ${ }^{7}$ Without examining the practices of knowledge production occurring at the margins, scholars lack a comprehensive understanding of how science itself works, that is, how it is created, consumed, and disseminated. We recognize that these six case studies are just a beginning; moreover, our focus on gender is but one possible category of analysis. Class, race, and ethnicity will be essential to 
the development of a richer and more accurate portrait of how knowledge has been produced in different times and different places. This issue is an invitation to further explore histories of scientific work beyond the academy.

\section{Acknowledgements}

Special thanks for discussing the concept of the working group's approach go to all the contributors of this volume, as well as to Mineke Bosch, Lorraine Daston, Poly Giannkopoulou, Liesbeth Hesselink, Nina Lerman, Constance Putnam, and Ruth Oldenziel.

\section{NOTES}

1. The relevant literature is vast. For a rich, informative, and wide ranging survey of the discipline, especially of the history of experimental sciences throughout the modern period, see volumes 4 and 5 of The Cambridge History of Science (Nye, 2003; Porter, 2003).

2. As Steven Shapin has argued, the western tradition has been generally unconcerned with the place of knowledge in accounts of truth, based on the assumption that by definition universal knowledge does not belong to any social place (Shapin, 1991, 1998). However, in the last decade, historians of geography, historians of science, sociologists, anthropologists, and science studies scholars have been intensively engaged in studies of the spatiality of scientific activity. The 'geographical' or 'spatial turn' is evident both in the recent literature of geography and of history of science. For an interdisciplinary and well-informed overview of this emerging field of studies see Powell (2007), especially pp. 315,327 . For a very recent collection of essays that 'think geographically,' especially about 19th-century science, see Livingston and Withers (2011). It is important to note that this spatial turn has especially informed studies of early modern science. It is indicative that the second set of essays in the Cambridge History of Science vol. 3 on the early modern period is titled, 'Personae and Sites of Natural Knowledge.' (Daston and Park, 2006).

3. The historiographical interest in the popularization of science was reflected in the definitive essay of Cooter and Pumfrey (1994). As early as 1990 Steven Hilgartner proposed the continuity model of scientific communication, criticizing the sharp distinction between science and its popularization (Hilgartner, 1990). For more recent and very fruitful discussions of the distinction between popularized and academic science see, for example, Bensaude-Vincent (2001), Secord (2004), Lightman and Fyfe (2007), Lightman (2007) and Topham (2009).

4. It was the work of historian George Daniels at the end of the 1960s that drew attention to professionalization as 'the most significant development in 19th century American science.' (Daniels, 1967, 1968). For a recent and provocative account of the professionalization of science in the 19th century in the USA see Lucier (2009). For historians' appropriation of the concept of professionalization by sociologists in the 1960s see Rosenberg, C. E. (1983). On the emergence of the research university in Western Europe, see Clark (2006).

5. Using the astronomers' Gottlieb and Maria Kirch-Winkelmann's family as an example, Londa Schiebinger gave a vivid description of this phenomenon (Schiebinger, 1991). For a collection of milestone essays in the field, see Kohlstedt (1999). For a comprehensive investigation of the challenges faced by American women scientists because of institutional exclusions over the last two centuries, see Margaret Rossiter's seminal three volumes of Women Scientists in America (Rossiter, 1982, 1995, 2012). For more recent accounts of gender, science, and technology in the US and Europe, see Štrbánová, Stamhuis and Mojsejová (2004); see also Pycior, Slack and Abir-Am (1996), 
Canel, Oldenziel and Zachmann (2000), Smith (2000), Lerman, Oldenziel and Mohun (2003), Mazon (2003), Bosch (2006), Coen (2007) and Lykknes, Opitz and van Tiggelen (2012). For special reference to gender and the physical sciences see Kohlstedt and Rentetzi, (2009); for the context of genetics see Richmond (2006), Stamhuis and Monsen (2007) and Satzinger (2012).

6. What historians of science have attempted to do is to dissolve the distinctions between inside and outside of scientific laboratories, institutions, and academia and to focus on the production of scientific knowledge as a process of 'mixed artisanal and learned practice' (Klein and Spary, 2010: 7), or as a number of 'hybrid activities involved in the intimately related processes of material and knowledge production' (Roberts, Schaffer and Dear, 2007: 16). For an example of how an epistemic category can be studied as a scientific practice, see Daston and Lunbeck (2011). An excellent and inspiring example of how gender can be made fruitful within the context of practices to reshape the history of a discipline is Katherine Park's account of the female body in mediaeval anatomy (Park, 2006).

7. We have borrowed the concept of the margins from Mary Fissell, who uses it to describe the project of cultural history. 'Cultural history,' she writes, 'can be understood as an attempt to take some of the methods and questions of intellectual history (Why did he think that? Where did she learn this?) and apply them to members of social groups whose thoughts had not previously been considered of historical interest.' Like Fissell, we do not mean to imply that historical actors at the margins were marginal; rather, we use the concept to draw explicit attention to these hitherto unstudied groups and individuals (Fissell, 2004, quote on 365).

\section{REFERENCES}

Bensaude-Vincent, B. (2001) A enealogy of the increasing gap between science and the public, Public Understanding of Science, 10, 99-113.

Bosch, M. (2006) Curious careers: an unexpected history of women in science and technology (Eindhoven: Foundation for the History of Technology).

Canel, A., Oldenziel, R. and Zachmann, K. (2000) Crossing boundaries, building bridges: comparing the history of women engineers, 1870s-1990s (London: Routledge).

Clark, W. (2006) Academic charisma and the origins of the research University (Chicago: University of Chicago Press).

Coen, D. (2007) Vienna in the age of uncertainty. science, liberalism, and private life (Chicago: University of Chicago Press).

Cooter, R. and Pumfrey, S. (1994) Separate spheres and public spaces: reflections on the history of science popularization and science in popular culture, History of Science, 32, 237-267.

Daniels, G. (1967) The process of professionalization in American science: the emergent period, 1820-1860, Isis, 58, 151-166.

Daniels, G. (1968) American science in the age of Jackson (New York: Columbia University Press).

Daston, L. and Lunbeck, E. (2011) Histories of scientific observation (Chicago: University of Chicago Press).

Daston, L. and Park, K. (2006) The Cambridge History of Science, Vol. 3: Early modern science (Cambridge: Cambridge University Press).

Fissell, M. (2004) Making medicine from the margins: the new cultural history of medicine, in: F. Huisman and J. H. Warner (eds.) Locating medical history: the stories and their meanings (Baltimore: Johns Hopkins University Press), pp. 364-389.

Hilgartner, S. (1990) The dominant view of popularization: conceptual problems, political uses, Social Studies of Science, 20, 519-539.

Klein, U. and Spary, M. (2010) Materials and expertise in early modern Europe: between market and laboratory (Chicago: University of Chicago Press).

Kohlstedt, S. G. (1999) History of women in the sciences: readings from isis (Chicago: University of Chicago Press).

Kohlstedt, S. G. and Rentetzi, M. (2009) Introduction: gender and networking in twentieth-century physical sciences, Centaurus, 51, 5-11. 
Lerman, N., Oldenziel, R. and Mohun, A. P. (2003) Gender and technology. A reader (Baltimore: Johns Hopkins University Press).

Lightman, B. (2007) Victorian popularizers of science: designing nature for new audiences (Chicago: University of Chicago Press).

Lightman, B. and Fyfe, A. (2007) Science in the marketplace: nineteenth-century sites and experiences (Chicago: University of Chicago Press).

Livingston, D. and Withers, C. (2011) Geographies of nineteenth century science (Chicago: University of Chicago Press).

Lucier, P. (2009) The professional and the scientists in the nineteenth century America, Isis, 100, 699-732.

Lykknes, A., Opitz, D. and van Tiggelen, B. (2012) For better or for worse? Collaborative couples in the sciences (Basel: Birkhäuser).

Mazon, P. M. (2003) Gender and the modern research university: the admission of women to German higher education, 1865-1914 (Stanford: Stanford University Press).

Nye, M. J. (2003) The Cambridge History of Science, Vol. 5: The modern physical and mathematical sciences (Cambridge: Cambridge University Press).

Park, K. (2006) Secrets of women: gender, generation, and the origins of human dissection (New York: Zone Books),

Porter, R. (2003) The Cambridge History of Science, Vol. 4: Eighteenth-century science (Cambridge: Cambridge University Press).

Powell, R. (2007) Geographies of science: histories, localities, practices, futures, Progress in Human Geography, 31(3), 309-329.

Pycior, H. M., Slack, N. G. and Abir-Am, P. G. (1996) Creative couples in the sciences (New Brunswick: Rutgers University Press).

Richmond, M. L. (2006) The 'domestication' of heredity: the familial organization of geneticists at Cambridge University, 1895-1910, Journal of the History of Biology, 39, 565-605.

Roberts, L., Schaffer, S. and Dear, P. (2007) The mindful hand: inquiry and invention from the late renaissance to early industrialism (Amsterdam: Edita).

Rosenberg, C. E. (1983) Science in American society: a generation of historical debate, Isis, 74, 356-367.

Rossiter, M. (1982) Women scientists in America. Struggles and strategies to 1940 (Baltimore: Johns Hopkins University Press).

Rossiter, M. (1995) Women scientists in America: before affirmative action, 1940-1972 (Baltimore: Johns Hopkins University Press).

Rossiter, M. (2012) Women scientists in America: forging a new world since 1972 (Baltimore: Johns Hopkins University Press).

Satzinger, H. (2012) The politics of gender concepts in genetics and hormone research in Germany, 1900-1950, Gender History Across Epistemologies (special issue of Gender and History), 24, 735-754.

Schiebinger, L. (1991) The mind has no sex? Women in the origins of modern science (Cambridge: Harvard University Press).

Secord, J. (2004) Knowledge in transit, Isis, 95, 654-672.

Shapin, S. (1991) 'The mind in its own place': science and solitude in seventeenth century England, Science in Context, 4, 191-218.

Shapin, S. (1998) Placing the view from nowhere: historical and sociological problems in the location of science, Transactions of the Institute of British Geographers, 23, 5-12.

Smith, B. (2000) The gender of history: men, women, and historical practice (Cambridge: Harvard University Press).

Stamhuis, I. H. and Monsen, A. (2007) Kristine Bonnevie, Tine Tammes and Elisabeth Schiemann in early genetics: emerging chances for a university career for women, Journal of the History of Biology, 40, 427-466.

Štrbánová, S., Stamhuis, I. H. and Mojsejová, M. (2004) Women scholars and institutions, in: Proceedings of the conference held 8-11 June 2003 in Prague, Vol. 13 and 14 (Prague: Studies in the History of Sciences and Humanities).

Topham, J. (2009) Focus: historicizing popular science, introduction, Isis, 100, 310-368. 